\title{
Effect of Clostridium butyricum on Gastrointestinal Infections
}

\author{
Tadashi Ariyoshi ${ }^{1,2}$, Mao Hagihara ${ }^{1,3}$, Motomichi Takahashi ${ }^{1,2}$ and Hiroshige Mikamo ${ }^{1,3, *}$ \\ 1 Department of Clinical Infectious Diseases, Aichi Medical University, Nagakute 480-1195, Aichi, Japan; \\ t.ariyoshi@miyarisan.com (T.A.); hagimao@aichi-med-u.ac.jp (M.H.); \\ motomichi.takahashi@miyarisan.com (M.T.) \\ 2 Miyarisan Pharmaceutical Co., Ltd., Saitama City 331-0804, Saitama, Japan \\ 3 Department of Molecular Epidemiology and Biomedical Sciences, Aichi Medical University, \\ Nagakute 480-1195, Aichi, Japan \\ * Correspondence: mikamo@aichi-med-u.ac.jp
}

check for updates

Citation: Ariyoshi, T.; Hagihara, M.; Takahashi, M.; Mikamo, H. Effect of Clostridium butyricum on Gastrointestinal Infections. Biomedicines 2022, 10, 483 . https://doi.org/10.3390/ biomedicines 10020483

Academic Editor: Sílvia A. Sousa

Received: 20 January 2022

Accepted: 15 February 2022

Published: 18 February 2022

Publisher's Note: MDPI stays neutral with regard to jurisdictional claims in published maps and institutional affiliations.

Copyright: (C) 2022 by the authors. Licensee MDPI, Basel, Switzerland. This article is an open access article distributed under the terms and conditions of the Creative Commons Attribution (CC BY) license (https:// creativecommons.org/licenses/by/ $4.0 /)$.

\begin{abstract}
Clostridium butyricum is a human commensal bacterium with beneficial effects including butyrate production, spore formation, increasing levels of beneficial bacteria, and inhibition of pathogenic bacteria. Owing to its preventive and ameliorative effects on gastrointestinal infections, C. butyricum MIYAIRI 588 (CBM 588) has been used as a probiotic in clinical and veterinary medicine for decades. This review summarizes the effects of $C$. butyricum, including CBM 588, on bacterial gastrointestinal infections. Further, the characteristics of the causative bacteria, examples of clinical and veterinary use, and mechanisms exploited in basic research are presented. C. butyricum is widely effective against Clostoridioides difficile, the causative pathogen of nosocomial infections; Helicobacter pylori, the causative pathogen of gastric cancer; and antibiotic-resistant Escherichia coli. Accordingly, its mechanism is gradually being elucidated. As C. butyricum is effective against gastrointestinal infections caused by antibiotics-induced dysbiosis, it can inhibit the transmission of antibioticresistant genes and maintain homeostasis of the gut microbiome. Altogether, C. butyricum is expected to be one of the antimicrobial-resistance (AMR) countermeasures for the One-health approach.
\end{abstract}

Keywords: gastrointestinal infection; Clostridium butyricum; gut dysbiosis; Clostridioides difficile; Helicobacter pylori

\section{Introduction}

Gastrointestinal infections, caused by the ingestion of pathogens and disruption of normal microbiota [1,2], mainly manifest as clinical syndromes, including acute vomiting, diarrhea, and enteric fever. These infections are induced by viruses, bacteria, protozoa, or parasites, such as norovirus, Shigella spp., Vibrio cholerae, Listeria monocytogenes, Enterohemorrhagic Escherichia coli (EHEC), Clostridioides difficile, and Salmonella spp. [3,4]. Some of the pathogens contain virulence factors, such as enterotoxins and flagella, which cause increased fluid secretion and decreased fluid absorption in the gut [5].

In previous randomized clinical studies and experimental studies using animal models, probiotics were found to reduce the severity of gastrointestinal infections and modulate host immunity [6-8]. Gram-positive Lactobacillus spp. and Bifidobacterium spp. have been widely used to treat or prevent gastrointestinal infection-associated diarrhea [9]. Additionally, many studies have reported that the short-chain fatty acids (SCFAs) produced by intestinal microbiota in the gut microbiome can affect host immune homeostasis and intestinal barrier function [10-12].

Similar to lactate, butyrate is one of the SCFAs produced as end-products of intestinal microbial fermentations $[13,14]$. Butyrate is rapidly absorbed in the gut and acts as a signaling molecule in receptor-mediated signaling in numerous cell types [15]. Prior to extensive efforts to sequence the gut microbiota, microbial butyrate production in the human gut was already known [16]. However, among the butyrate-producing bacteria, 
only Clostridium butyricum has been used as a probiotic for symptoms associated with gastrointestinal infections.

Despite accumulating evidence regarding C. butyricum, reviews of its effectiveness for gastrointestinal infections are limited compared with Bifidobacterium spp. and Lactobacillus spp. [17-22]. Therefore, this review seeks to discuss the excellent clinical efficacy and mechanism of C. butyricum, without limiting animal species, especially for gastrointestinal infections, which are frequently reported.

\section{Clostridium butyricum}

C. butyricum, a historical and beneficial symbiote, butyrate-producing, spore-forming, obligate anaerobe, and Gram-positive rod shape bacterium, is found in a variety of environments, including soil. C. butyricum is also detected in the human gut of approximately $20 \%$ of adults [23]. C. butyricum is symbiotic with its host, resides in the intestinal tract, and grows by fermenting dietary fiber and other materials that are not degraded by the host. During the fermentation process, $C$. butyricum mainly produces butyrate via the but-buk pathway [24].

In 1933, Dr. Miyairi isolated C. butyricum for the first time from the feces of healthy individuals [25]. Thereafter, C. butyricum MIYAIRI 588 (CBM 588), which was isolated from soil in 1963 [26], was formulated and has been widely used in Japan as a drug for gastrointestinal symptoms, such as diarrhea [27]. The safety of CBM 588 has been confirmed not only in preclinical studies under the good laboratory practice (GL) [28-31] and/or humans but also in broilers and pigs, and it has been used worldwide as a feed additive [32].

In Europe, CBM 588 is mostly prescribed for as a animals feed additive with improvement of zoo technical performance; however, it has been authorized for use as a novel food by the Council and the European Parliament [33].

Seki et al. [27] reported the preventive effect of CBM 588 for antibiotic-associated diarrhea (AAD) in children. CBM 588 was found to protect the gut mucin layer from antibiotic-induced dysbiosis [34,35]. Further, CBM 588 is known to promote mucin production by modulating the gut microbiota [36,37]. As intestinal epithelial cells under the mucin layer contain absorptive epithelial cells [38], a dysfunction of these cells leads to diarrhea induced by incomplete absorption of water in feces.

CBM 588 regulates the expression of various inflammatory and anti-inflammatory cytokines. CBM 588 also induces the differentiation of IL-17-producing $\gamma \delta \mathrm{T}$ cells, which are known to play a central role in the expression of mucins and tight junction proteins (TJs) in colonic epithelial cells $[39,40]$. Treatment with CBM 588 attenuates gut inflammation by altering host lipid metabolism due to the upregulation of protectin D1, an anti-inflammatory lipid mediator [41].

CBM 588 modulates the composition of the intestinal microbiota. Previous studies revealed that CBM 588 administration increased beneficial bacterial populations, such as Lactococcus spp., Lactobacillus spp., and Bifidobacterium spp. in the gut microbiota after antibiotic administration [37,40]. These protective effects of CBM 588 are expected to prevent pathogen colonization and enable the treatment of diarrhea in clinical practice.

\section{Gut Dysbiosis and Gastrointestinal Infections}

Gut dysbiosis is the constitutive and functional transformation of the gut microbiota by environment- and host-related factors [42], such as diet, chemotherapy, antibiotic therapy, stress, environment, infection, and genetic factors. The mammalian gut microbiota is a highly abundant and diverse microbial community that resides in the gastrointestinal tract [43]. When microbial diversity is reduced, the competition between bacteria is eliminated and some bacteria may grow abnormally.

For example, high oxygen concentration in the inflamed intestine allows aerobic respiration by Enterobacterales; however, this condition inhibits the growth of Bacteroidia and Clostridia, which are ubiquitous anaerobes. The abnormal growth of Enterobacterales promotes enterobactin production, a potent iron chelator that inhibits the bactericidal action 
of neutrophil myeloperoxidase. Additionally, local oxidative stress-causing agents and toxins produced by pathogens disrupt tight junctions in intestinal epithelial cells, resulting in the breakdown of the barrier function and the induction of a "leaky gut" [44-46].

Dysbiosis-induced mucosal damage leads to a decrease in the regulators of the innate immune system, such as Toll-like receptors (TLRs) and NOD-like receptors (NLRs), enabling pathogen invasion. Thereafter, a reduction in resistance due to the decreased production of mucus, antibacterial peptides, and immunoglobulin A (IgA) antibodies result in colonization by pathogenic bacteria $[47,48]$.

\section{Bacterial Gastrointestinal Infections}

\subsection{Clostridioides difficile Infection}

C. difficile is an anaerobic, spore-forming, Gram-positive rod bacteria that mainly uses succinic acid, primary bile acids, and sialic acid as a source of nutrition for growth in the colon [49]. During the growth phase, $C$. difficile produces toxin A/B (TcdA/TcdB) to target Rho proteins in the host cell. Consequently, the actin cytoskeleton, which is normally maintained by RhoA, is disrupted, causing cell death, mucosal injury, and inflammatory cytotoxicity [50,51] (Figure 1).

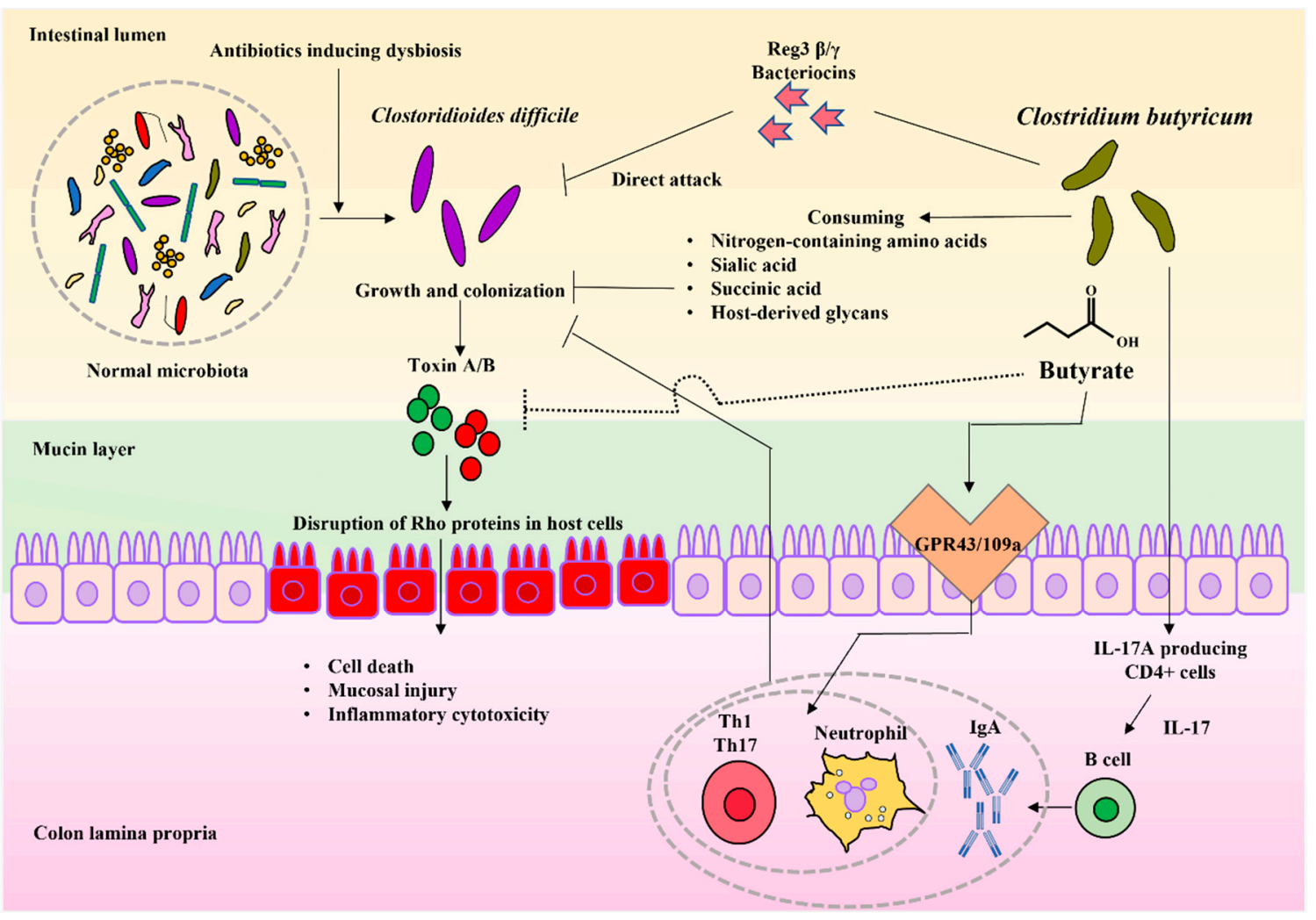

Figure 1. The mechanisms whereby C. butyricum protects against Clostridioides difficile infection: C. difficile survives when treated with antibiotics and becomes predominant during dysbiosis. C. difficile infection (CDI) is established by colonization and toxin A/B production, which disrupts the cytoskeletal homeostasis maintained by Rho proteins, inducing inflammation and cell death. In contrast, C. butyricum inhibits CDI via the following mechanisms: I: direct attack by the production of antimicrobial substances, II: growth with indigenous bacteria to inhibit the growth of $C$. difficile from nutritional conditions, III: inhibition of toxin activity by butyrate, IV: induction of neutrophils, Th1 and Th17 cells by butyric acid to eliminate C. difficile, V: activation of IL-17A-producing cells to induce B cells, and the production of IgA to eliminate $C$. difficile. Solid lines indicate mechanisms that have been already reported. Dashed lines indicate expected mechanisms. Arrows indicate active pathways. The T-shaped lines indicate the inhibitory pathway. 
C. difficile infection (CDI) is one of the major causes of nosocomial diarrhea worldwide. CDI associates with gut dysbiosis and causes mild diarrhea to severe colitis [52]. Previous clinical study reported that approximately $90 \%$ of pseudomembranous enteritis and $25-33 \%$ of antibiotic-associated diarrhea are attributed to CDI [53]. Additionally, CDI increased patient morbidity and decreased quality of life. Consequently, CDI prolonged hospitalization [54-56].

In a clinical study, the co-administration of CBM 588 and vancomycin had a beneficial effect on the treatment of CDI [57]. Among 71 patients with CDI, the co-administration of CBM 588 and antibiotics reduced the stool frequency on the second day of treatment (vancomycin alone group vs. vancomycin plus CBM 588: 3.9 times/day vs. 2.6 times/day, $p<0.05)$. Furthermore, compared with vancomycin monotherapy, the co-administration of CBM 588 and vancomycin shortened the treatment periods from 10.9 days to 8.9 days. However, no similar effect was demonstrated by co-administration with Enterococcus faecium product.

In in vivo experiments with the $\mathrm{CDI}$ model, the incidence of diarrhea was significantly decreased in CBM 588-treated rats [58]. Additionally, CBM 588 reduced the mortality of mice [59] as well as cytotoxin production [59]. In an in vitro study, C. difficile decreased cytotoxin production when co-cultured with CBM 588. Further, the proliferation of $C$. difficile was suppressed [60]. Interestingly, these effects showed only at viable CBM 588, which means living and growth cells, contacted to the $C$. difficile cells. Moreover, it is considered that the direct contact with the metabolites of CBM 588 suppressed the toxin production and growth of $C$. difficile. Such findings suggest that CBM 588 attenuated symptoms related to CDI (Figure 1).

Competition for nutrient sources during the bacterial growth phase is one of the mechanisms by which probiotics enhance the resistance to pathogen colonization. Probiotic bacteria and normal gut microbiota are reported to inhibit $C$. difficile growth by consuming nitrogen-containing amino acids, sialic acid, succinic acid, and host-derived glycans, which are nutrient sources for $C$. difficile, and by producing SCFAs [61-63] (Figure 1).

Hagihara et al. reported that CBM 588 not only modulated gut microbiota, but negatively modulated gut succinate levels to prevent the growth of $C$. difficile and downregulate tumor necrosis factor- $\alpha$ (TNF- $\alpha)$, ultimately producing macrophages in the colon lumina propria (cLP), which led to a significant decrease in colon epithelial damage. CBM 588 also upregulated T cell-dependent pathogen specific IgA by IL-17A producing $\mathrm{CD} 4^{+}$cells and plasma B cells in the cLP. Th17 cells in the cLP were found to promote the gut epithelial barrier function, ultimately enhancing the colonization resistance of $C$. difficile [61] (Figure 1).

The secretion of substances that inhibit the production or activity of TcdA/TcdB counteracts toxicity to enhance $C$. difficile colonization resistance $[64,65]$. Bacteriocins, a class of antibiotic peptides, are direct weapons that can be secreted by probiotics [66]. As this bacteriocin is only effective against analogous bacteria, it has gained attention for eliminating the target bacteria without disturbing the microbiota (Figure 1).

Recent studies have shown that the stimulation of host immunity by CBM 588 is effective against CDI. By administering CBM 588 to CDI-infected mice, Hayashi et al. demonstrated that (1) butyrate produced by CBM 588 acted as an antibiotic peptide for $\operatorname{Reg} 3 \beta \gamma$, (2) butyrate-induced neutrophils were not only induced through GPR43/109a signaling but also by metabolites besides butyrate, and (3) Th1 and Th17 cells are induced by butyrate-mediated GPR43/109a signaling [67] (Figure 1).

\subsection{Helicobacter pylori Infection}

Helicobacter pylori is a Gram-negative, helical, microaerophilic, flagellate bacterium [68]. This pathogen is known as a gastric carcinogen, and its eradication is associated with the incidence of gastric cancer [69-71]. However, H. pylori has excellent defense mechanisms, such as gastric acid resistance by urease and drug resistance by biofilm formation [72,73] (Figure 2). 


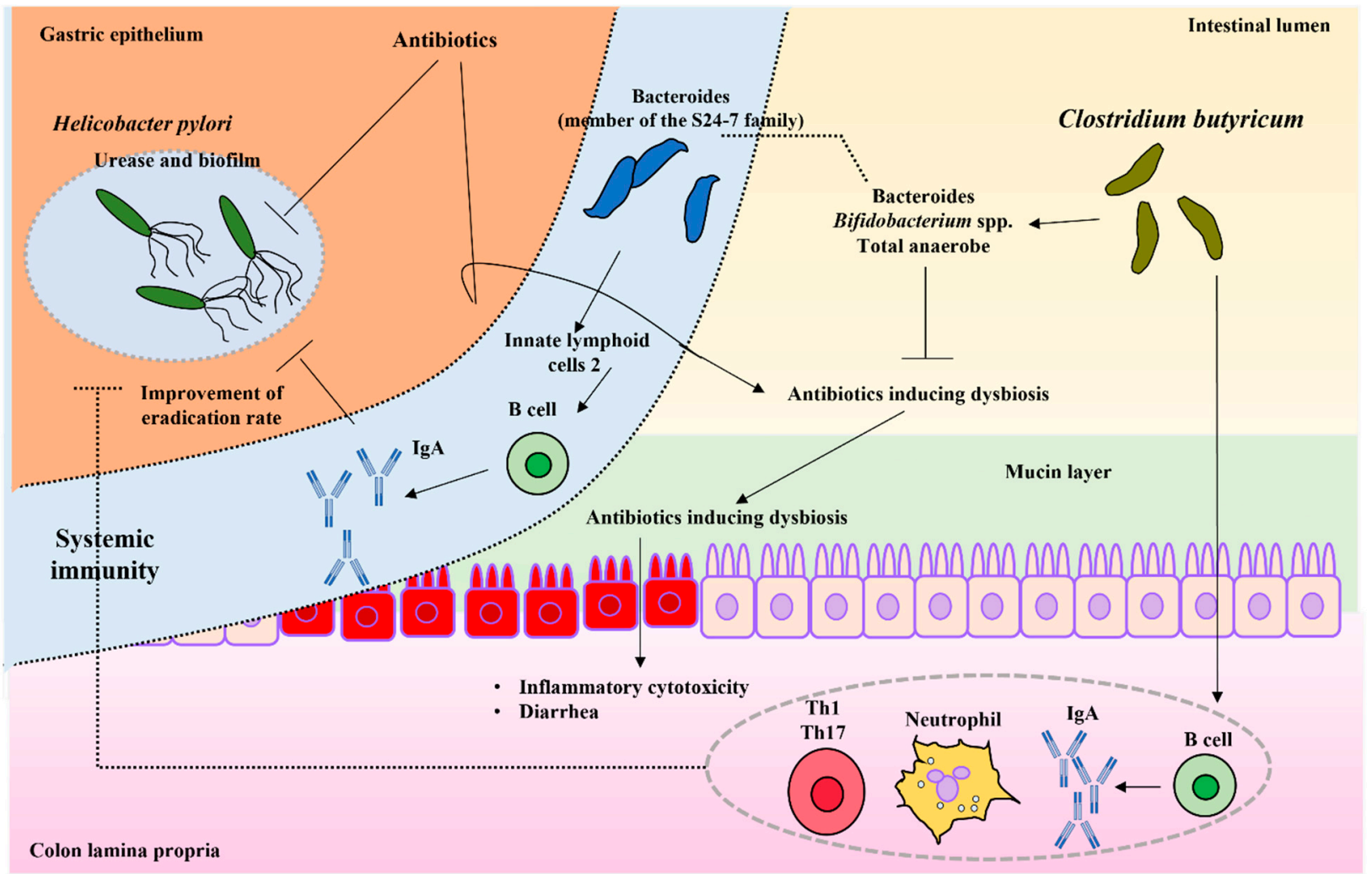

Figure 2. The protective mechanisms from H. pylori infection with C. butyricum: antibiotic eradication therapy is employed for $H$. pylori infection. As a result, dysbiosis is induced; however, the anaerobic bacteria, Bacteroides and Bifidobacterium spp. are retained by the administration of C. butyricum with no reduction in their numbers. C. butyricum increases the eradication rate of $H$. pylori owing to the following reasons: I: systemic immunity is activated, which helps to eliminate $H$. pylori in the stomach, II: Bacteroides (a member of the S24-7 family) is involved in innate 2 (ILC2) in the stomach, and IL-5 released from ILC2 stimulates B cells to produce IgA. Solid lines indicate mechanisms that have been already reported. Dashed lines indicate expected mechanisms. Arrows indicate active pathways. The T-shaped lines indicate the inhibitory pathway.

Mukai et al. retrospectively evaluated the eradication rate in 468 patients with $H$. pylori infection. Based on their results, the rate was significantly higher in patients administered proton pump inhibitors (PPIs) and CBM 588 (87.1\%) than those administered PPIs alone (70.1\%) [74]. Additionally, the co-administration of CBM 588 and PPI reduced the incidence of diarrhea or soft stool during H. pylori eradication therapy $(43 \%$ in the control group and 14\% in the CBM 588 normal dose group, and 0\% in the CBM 588 double dose group) [74].

Although the number and detection rate of Bifidobacterium spp. and ectopic anaerobes were found to be reduced by the antibiotic eradication therapy [75], the number of ectopic anaerobes in the CBM 588 double-dose group was significantly higher than that in the control group [75]. Thus, CBM 588 can contribute to the maintenance of gut microbiota homeostasis and improve the bactericidal effect against H. pylori (Figure 2).

Chen et al. reported an increase in Bacteroides spp. and a decrease in gastrointestinal symptoms with CBM 588 administration [76]. Bacteroides, a member of the S24-7 family, has been reported to increase the number of innate lymphoid cells 2 (ILC2) in the stomach. Further, IL-5 released from ILC2 stimulates B cells to produce IgA [77]. However, the mechanism involved in the improvement of the eradication rate of $H$. pylori owing to the combination of probiotics, including CBM 588, is unclear (Figure 2).

The effect of CBM 588 on $H$. pylori infection has been reported based on basic research. Takahashi et al. [78] reported that CBM 588 culture supernatant inhibited the growth of $H$. pylori; this inhibitory effect was observed even when the culture supernatant was 
adjusted to $\mathrm{pH} 7$, indicating a dependence on the butyrate produced. Furthermore, the inoculation of $H$. pylori-infected gnotobiotic mice with CBM 588 reduced the number of H. pylori bacteria to less than $1 / 100$ [78].

The adhesion of $H$. pylori to gastric epithelial cells is a primary event in the development of infection. As Lactobacillus spp. inhibit the adhesion of H. pylori to MKN45 and Caco-2 cells $[79,80]$, CBM 588 displayed an inhibitory effect on the adhesion of $H$. pylori to MKN45 cells [81]. However, it is still unclear how CBM 588 inhibited the attachment of H. pylori to gastric epithelial cells (Figure 2).

The gut microbiota and its metabolites are markedly altered in patients after gastrectomy [81]. Future studies are expected to investigate the effects on the stomach owing to the changes in the gut microbiota. Most bacteria are useful as probiotics colonize the colon while H. pylori colonize the stomach. Hence, it is unlikely that probiotics are directly involved in the lurking of $H$. pylori in the stomach. Nevertheless, the enhanced eradication effect may be attributed to the improvement of systemic immunity due to immunostimulation by probiotics $[82,83]$ (Figure 2).

\subsection{Escherichia coli Infection}

E. coli is a facultative anaerobic, Gram-negative rod-shaped bacterium. This bacterium is usually found in the intestines of animals and healthy people. Most types of E. coli are harmless and induce mild diarrhea in a relatively shorter period of time. However, E. coli O157:H7, can cause severe abdominal pain, vomiting, bloody diarrhea, and stomach cramps $[84,85]$ (Figure 3).

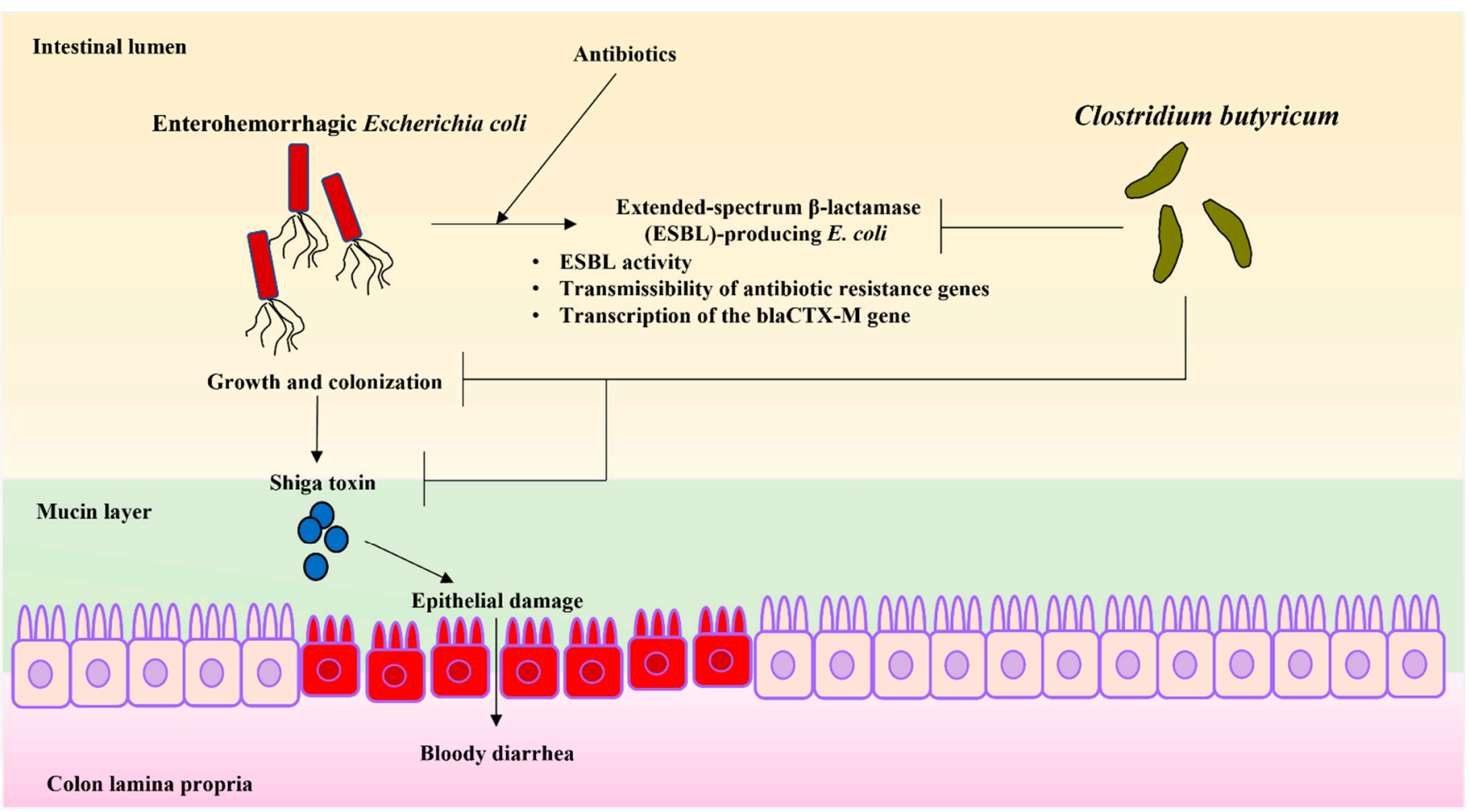

Figure 3. The mechanisms whereby C. butyricum protects against enterohemorrhagic E. coli (EHEC) infection. EHEC causes hemorrhagic diarrhea. CBM 588 alleviates this symptom by inactivating EHEC growth and toxin. Although infections caused by E. coli are treated with antibiotics, the development of resistance is concerning. CBM 588 has been reported to have the following effects on the development of resistance in E. coli. I: inactivation of ESBLs, II: repression of the transcription of the blaCTX-M gene during the growth phase of E. coli, III: inhibition of the transmissibility of antibiotic resistance genes by enteric bacteria. Solid lines indicate mechanisms that have been already reported. Arrows indicate active pathways. The T-shaped lines indicate the inhibitory pathway. 
Additionally, enterohemorrhagic E. coli (EHEC), one of E. coli strain, causes serious intestinal infection. EHEC produces a potent toxin called Shiga toxin. This toxin causes bloody diarrhea after distractions of the lining of the intestinal wall $[84,85]$. EHEC outbreaks have also been linked to some types of foods, as well as surface water areas that animals visited frequently.

Although no clinical study has evaluated the efficacy of C. butyricum to EHEC infection, Fujita et al. [86] reported that butyrate produced by CBM 588 reduced the titer of thermophilic enterotoxin regardless of $\mathrm{pH}$ in an in vivo study; however, the mechanisms remain unclear. Additionally, the therapeutic administration of CBM 588 to EHEC infected mice reduced the mortality by 50\%. Thereafter, prophylactic administration of CBM 588 reduced the mortality to $0 \%$. CBM 588 also reduced the number of EHEC in the gut and the toxin titer in the feces of infected mice. These results suggest that CBM 588 has preventive and therapeutic effects against EHEC [87] (Figure 3).

In vitro studies revealed that the co-culture of CBM 588 and EHEC inhibited the growth of EHEC and reduced their toxin production [88]. Butyrate was found to be involved in these inhibitory effects, and caused $\mathrm{pH}$-independent and dose-dependent antibacterial effects on EHEC. The preincubation of CBM 588 with Caco-2 cells inhibited the establishment of EHEC [87] (Figure 3).

Kunishima et al. [88] investigated the effects of CBM 588 on the growth, $\beta$-lactamase activity, and transmissibility of the antibiotic resistance properties of antimicrobial-resistant (AMR) organisms, including extended-spectrum $\beta$-lactamase (ESBL)-producing E. coli and carbapenem-resistant Enterobacterales. Consequently, the growth of AMR bacteria was inhibited in a dose-dependent manner by the supernatants of Clostridium spp. containing CBM 588 (Figure 3).

The $\beta$-lactamase activity produced by $E$. coli was found to be reduced in the presence of CBM 588 culture supernatant. Further, the transcription of the blaCTX-M gene is repressed during the growth phase of E. coli. A conjugation assay revealed a decrease in the transmissibility of antibiotic resistance genes by enteric bacteria. These results suggest that CBM 588 can be employed to suppress AMR bacteria [88] (Figure 3).

\subsection{Staphylococcus aureus Infection}

S. aureus is a Gram-positive round-shaped bacterium and a member of the body's microbiota as it is frequently found in the upper respiratory tract and the skin [89]. S. aureus isolates can produce a variety of enterotoxins and enterotoxin-like substances [90]. Hence, the presence of $S$. aureus in the gastrointestinal tract can result in colonization, food-borne disease, enterocolitis, and toxic shock syndrome [91].

As a recent report suggested that $C$. butyricum alleviates intestinal injury through epidermal growth factor receptor (EGFR) [92,93], Ma et al. [94] evaluated the inhibitory effects of the recombinant strain of C. butyricum overexpressing EGF. The recombinant strain significantly inhibited the growth of co-cultured $S$. aureus. An inhibitor was then used to block STAT3 tyrosine phosphorylation, decreasing the antibacterial effect of the recombinant strains.

Compared with the wild-type strain, the recombinant strain increased the expression levels of intestinal formation-related genes (Claudin-1, GLUT-2, SUC, GLP2R, EGFR) and anti-inflammatory genes $(I L-10)$ in intestinal epithelial cells [94]. Hence, the secretory overexpression of pEGF in C. butyricum could upregulate the expression level of EGFR, consequently improving the intestinal protective functions of $C$. butyricum partly following STAT3 signal activation in IPECs, causing a positive loop.

\subsection{Vibrio cholerae Infection}

$V$. cholerae is a facultative anaerobic, Gram-negative bacilliform bacterium [95]. This bacterium is found in marine and brackish waters. Additionally, this bacterium adheres to the chitinous shells of shellfish such as shrimp and crabs. Some strains of $V$. cholerae are 
pathogenic to humans and cause cholera, a fatal disease that originates from the ingestion of raw or undercooked marine species [96].

Kuroiwa et al. [97] investigated the inhibitory effect of CBM 588 on various enteric pathogens in vitro. CBM 588 inhibited the growth of $V$. cholerae O1, $V$. cholerae non-O1, Aeromonas hydrophila, and Shigella flexneri in co-culture. Furthermore, the inhibitory effect was observed when the $\mathrm{pH}$ was kept neutral, suggesting that not only the low $\mathrm{pH}$ conditions, but also the metabolites produced contributed to the inhibitory effect of each pathogen [97].

\subsection{Salmonella Species Infection}

S. enterica is an aerobic, Gram-negative flagellated and rod-shaped bacterium. S. enterica causes most salmonellosis originated from infected foods [98]. To develop infectious diseases induced by S. enterica, secreted proteins are important. Salmonella spp. can mediate biofilm formation and readily contact with host cells, because of a very large number of fimbrial and nonfimbrial adhesins. Their secreted proteins also play a role in host cell invasion and intracellular growth.

CBM 588 suppressed enteritis caused by Salmonella spp. in farm pigs and significantly reduced mortality [99]. Additionally, in an in vivo study with specific pathogen-free (SPF) broilers infected with S. enteritidis, C. butyricum altered the gut microbiota composition and increased the $\alpha$-diversity [100]. Further, C. butyricum caused the downregulation of inflammation cytokine levels (IFN- $\gamma$, IL-1 $\beta$, IL-8, TNF- $\alpha$ ) in intestinal tissues and upregulation of muc-2 and ZO-1 expression levels [100].

\section{Conclusions}

The cause of some gastrointestinal infections can be explained by microscopic mechanisms in the intestinal tract where dysbiosis occurs. Hence, maintaining gut microbiota homeostasis is one of the main purposes of ameliorating some symptoms of gastrointestinal infections. It is also known that the damage to the intestinal tract can be caused by abnormal growth of pathogenic bacteria and associated toxin production [101,102].

Previous in vivo and in vitro study revealed that CBM 588 would be effective to inhibit the proliferations of bacteria and can cause gastrointestinal infections [57-67,74-83,86-88,92$94,97,99,100]$. Additionally, CBM 588 is a very safe drug since the bacteria has no toxinproducing genes and has been used clinically for over 70 years [25-32]. Therefore, CBM 588 is expected to be effective not only for diarrhea in dysbiosis caused by antibiotics but also for diarrhea in dysbiosis caused by pathogenic bacteria.

By now, no clinical evidence has shown that CBM 588 can reduce pathogenic bacteria in gut by itself. However, there are some supportive in vivo and in vitro study data showing that CBM 588 would be effective in inhibiting the proliferations of bacteria and can cause gastrointestinal infections by butyrate production, nutritional competition, and production of antibiotic substances such as bacteriocins $[61,66,67,78,86,87]$.

Additionally, we are thinking that one of the therapeutic purposes to use probiotics is to inhibit the recurrence and colonization of pathogenic bacteria. Then, some clinical studies have suggested that $C$. butyricum strains not only inhibit many pathogenic bacteria growth, but also enhance host intestinal immunity.

In the case of clinical study, the co-administration of CBM 588 with antibiotics before the onset of diarrhea significantly reduced the incidence of diarrhea [27]. Furthermore, in EHEC-infected rabbit models, prior administration of C. butyricum inhibited the growth of EHEC and reduced the incidence of diarrhea and the lethality [103]. In addition, CBM 588 administration prior to CDI induced Th1, Th17, and neutrophils and enhanced C. difficile colonization resistance, thereby reducing the lethality [68]. Hence, prior colonization of C. butyricum in gut is expected to inhibit the invasion of pathogenic bacteria and to maintain the homeostasis of the microbiota.

SCFAs produced by gut microbiota are known to contribute to host health by regulating intestinal immune homeostasis [104-106]. Among them, butyrate can not only inhibit 
pathogenic bacteria growth by lowering $\mathrm{pH}$, but also serves as a source of energy for mucosal cells in the colon [107]. Butyrate stimulates receptors in the colon to promote intestinal peristalsis [108-110], and promotes mucus secretion in the colon, ultimately contributing to the inhibition and elimination of pathogenic bacteria in the intestinal tract [111].

Butyrate has been reported to activate the host SCFAs receptors, such as GPR43 and 109a, and to exhibit anti-inflammatory effects [112]. Butyrate also directly promotes the differentiation of Tregs by inhibiting histone deacetylases (HDACs) [113,114]. Taken together, butyrate-producing C. butyricum is very beneficial to the regulation of gastrointestinal infections and further explorations are needed to identify new targets for the prevention of gastrointestinal infections.

We focused on other fatty acid metabolites related to SCFAs and their receptors. By administering CBM 588 to mice with antibiotic-induced gut dysbiosis, we analyzed the immune response of the host intestinal tract, intestinal microbiota, and fecal metabolites [115]. Consequently, the following results were obtained. 1: CBM 588 increased the production of anti-inflammatory omega-3 fatty acids and anti-inflammatory lipid mediators by modulating gut microbiota; and 2: CBM 588 affected lipid metabolites and increased the conversion of linoleic acid metabolites, which are ligands for the fatty acid receptor, GPR120 [115].

Changes in the lipid metabolism of gut microbiota and the host were confirmed by the administration of CBM 588 [115]. The unsaturated fatty acids induced by CBM 588 are expected to contribute to the termination of inflammatory symptoms in gastrointestinal infections. Therefore, the metabolites in feces and gut microbiota should be analyzed and discussed based on the results of multi-omics research.

Although this review has specifically discussed bacterial gastrointestinal infections, some studies have shown that probiotics such as Lactobacillus spp. and Bifidobacterium spp. have antiviral effects [116-118]. Evidence showing the anti-viral effect of $C$. butyricum has not been confirmed. However, CBM 588 induces cytokines and immune cells with anti-viral effects, including IFN- $\gamma$ and / or IgA, in various models. Hence, CBM 588 may indirectly inhibit virus infection through Lactobacillus and Bifidobacterium species proliferations [61,67]. Moreover, protectin D1, the metabolite induced by CBM 588 in antibiotic causing dysbiosis model, inhibits viral RNA transport to the nuclear envelope, thereby suppressing influenza virus replication [119].

In conclusion, butyrate-producing CBM 588 is presently making a significant contribution to the endless number of fatalities caused by gastrointestinal infections. Alleviating the crisis caused by gastrointestinal pathogens in animals, including humans, is the mission of future probiotic products. Additionally, C. butyricum can serve as one of the AMR countermeasures, enabling us to tackle future global problems, as this bacteria can inhibit the transmission of antibiotic-resistant genes and maintain gut microbiota homeostasis.

Author Contributions: Conceptualization, T.A., M.H., M.T. and H.M.; writing-original draft preparation, T.A. and M.H.; writing-review and editing, T.A., M.H., M.T. and H.M. All authors have read and agreed to the published version of the manuscript.

Funding: This research received no external funding.

Institutional Review Board Statement: Not applicable.

Informed Consent Statement: Not applicable.

Data Availability Statement: Not applicable.

Conflicts of Interest: T.A. and M.T. are employees of Miyarisan Pharmaceutical Co., Ltd. The authors declare no conflict of interest.

\section{References}

1. Saberpour, M.; Bakhshi, B.; Najar-Peerayeh, S. Evaluation of the Antimicrobial and Antibiofilm Effect of Chitosan Nanoparticles as Carrier for Supernatant of Mesenchymal Stem Cells on Multidrug-Resistant Vibrio cholerae. Infect. Drug Resist. 2020, 13, 2251-2260. [CrossRef] [PubMed] 
2. Lim, S.C.; Knight, D.R.; Riley, T.V. Clostridium difficile and One Health. Clin. Microbiol. Infect. 2020, 26, 857-863. [CrossRef] [PubMed]

3. Payne, D.C.; Vinjé, J.; Szilagyi, P.G.; Edwards, K.M.; Staat, M.A.; Weinberg, G.A.; Hall, C.B.; Chappell, J.; Bernstein, D.I.; Curns, A.T.; et al. Norovirus and medically attended gastroenteritis in U.S. children. N. Engl. J. Med. 2013, 368, 1121-1130. [CrossRef] [PubMed]

4. Marder, E.P.; Cieslak, P.R.; Cronquist, A.B.; Dunn, J.; Lathrop, S.; Rabatsky-Her, T.; Ryan, P.; Smith, K.; Tobin-D’ Angelo, M.; Vugia, D.J.; et al. Incidence and Trends of Infections with Pathogens Transmitted Commonly Through Food and the Effect of Increasing Use of Culture-Independent Diagnostic Tests on Surveillance-Foodborne Diseases Active Surveillance Network, 10 U.S. Sites, 2013-2016. MMWR Morb. Mortal. Wkly. Rep. 2017, 66, 397-403, Erratum in MMWR Morb. Mortal. Wkly. Rep. 2017, 66, 653. [CrossRef]

5. Thiagarajah, J.R.; Donowitz, M.; Verkman, A.S. Secretory diarrhea: Mechanisms and emerging therapies. Nat. Rev. Gastroenterol. Hepatol. 2015, 12, 446-457. [CrossRef]

6. Takeda, K.; Suzuki, T.; Shimada, S.I.; Shida, K.; Nanno, M.; Okumura, K. Interleukin-12 is involved in the enhancement of human natural killer cell activity by Lactobacillus casei Shirota. Clin. Exp. Immunol. 2006, 146, 109-115. [CrossRef]

7. Oka, A.; Sartor, R.B. Microbial-Based and Microbial-Targeted Therapies for Inflammatory Bowel Diseases. Dig. Dis. Sci. 2020, 65, 757-788. [CrossRef]

8. Gopalakrishnan, V.; Helmink, B.A.; Spencer, C.N.; Reuben, A.; Wargo, J.A. The Influence of the Gut Microbiome on Cancer Immunity, and Cancer Immunotherapy. Cancer Cell 2018, 33, 570-580. [CrossRef]

9. Kandasamy, S.; Vlasova, A.N.; Fischer, D.D.; Chattha, K.S.; Shao, L.; Kumar, A.; Langel, S.N.; Rauf, A.; Huang, H.C.; Rajashekara, G.; et al. Unraveling the Differences between Gram-Positive and Gram-Negative Probiotics in Modulating Protective Immunity to Enteric Infections. Front. Immunol. 2017, 8, 334. [CrossRef]

10. Rooks, M.G.; Garrett, W.S. Gut microbiota, metabolites and host immunity. Nat. Rev. Immunol. 2016, 16, 341-352. [CrossRef]

11. Wang, Z.; Zhao, Y. Gut microbiota derived metabolites in cardiovascular health and disease. Protein Cell 2018, 9, 416-431. [CrossRef] [PubMed]

12. Chen, M.X.; Wang, S.Y.; Kuo, C.H.; Tsai, I.L. Metabolome analysis for investigating host-gut microbiota interactions. J. Formos Med. Assoc. 2019, 118 (Suppl. S1), S10-S22. [CrossRef] [PubMed]

13. Fleming, S.E.; Rodriguez, M.A. Influence of dietary fiber on fecal excretion of volatile fatty acids by human adults. J. Nutr. 1983, 113, 1613-1625. [CrossRef] [PubMed]

14. Flint, H.J.; Scott, K.P.; Louis, P.; Duncan, S.H. The role of the gut microbiota in nutrition and health. Nat. Rev. Gastroenterol. Hepatol. 2012, 9, 577-589. [CrossRef]

15. Zhang, L.; Liu, C.; Jiang, Q.; Yin, Y. Butyrate in Energy Metabolism: There Is Still More to Learn. Trends Endocrinol. Metab. 2021, 32, 159-169. [CrossRef] [PubMed]

16. Cummings, J.H.; Pomare, E.W.; Branch, W.J.; Naylor, C.P.; Macfarlane, G.T. Short chain fatty acids in human large intestine, portal, hepatic and venous blood. Gut 1987, 28, 1221-1227. [CrossRef]

17. Azad, M.A.K.; Sarker, M.; Li, T.; Yin, J. Probiotic Species in the Modulation of Gut Microbiota: An Overview. Biomed. Res. Int. 2018, 2018, 9478630. [CrossRef]

18. Gupta, V.; Garg, R. Probiotics. Indian J. Med. Microbiol. 2009, 27, 202-209. [CrossRef]

19. Sarao, L.K.; Arora, M. Probiotics, prebiotics, and microencapsulation: A review. Crit. Rev. Food Sci. Nutr. 2017, 57, 344-371. [CrossRef]

20. Tonucci, L.B.; Dos Santos, K.M.O.; Ferreira, C.L.D.L.F.; Ribeiro, S.M.R.; De Oliveira, L.L.; Martino, H.S.D. Gut microbiota and probiotics: Focus on diabetes mellitus. Crit. Rev. Food Sci. Nutr. 2017, 57, 2296-2309. [CrossRef]

21. Williams, N.T. Probiotics. Am. J. Health Syst. Pharm. 2010, 67, 449-458. [CrossRef] [PubMed]

22. Stoeva, M.K.; Garcia-So, J.; Justice, N.; Myers, J.; Tyagi, S.; Nemchek, M.; McMurdie, P.J.; Kolterman, O.; Eid, J. Butyrate-producing human gut symbiont, Clostridium butyricum, and its role in health and disease. Gut Microbes 2021, 13, 1-28. [CrossRef] [PubMed]

23. Finegold, S.M.; Sutter, V.L.; Mathisen, G.E. Normal indigenous intestinal flora. In Human Intestinal Microflora in Health and Disease; Hentges, D., Ed.; Academic Press: New York, NY, USA, 1983; pp. 3-28.

24. Vital, M.; Penton, C.R.; Wang, Q.; Young, V.B.; Antonopoulos, D.A.; Sogin, M.L.; Morrison, H.G.; Raffals, L.; Chang, E.B.; Huffnagle, G.B.; et al. A gene-targeted approach to investigate the intestinal butyrate-producing bacterial community. Microbiome 2013, 1, 8. [CrossRef] [PubMed]

25. Miyairi, C. Effect of hydrogen ion concentration on the development of intestinal microflora. Characterization of a new spore bacterium isolated from feces. (Suiso ion noudo no tyonaikinso no hatsuiku ni oyobosu eikyo, hunben yori bunriseru ichi shingahoukin no seijo nit suite). J. Chiba Med. School 1935, 3, 1102-1157. (In Japanese)

26. Miyarisan Pharmaceutical Co., Ltd. Clostridium Butyricum MIYAIRI Strain [Internet]. Clostridium Butyricum MIYAIRI Strain Available online: http:/ / www.miyarisan.com/english_index.htm (accessed on 8 January 2022).

27. Seki, H.; Shiohara, M.; Matsumura, T.; Miyagawa, N.; Tanaka, M.; Komiyama, A.; Kurata, S. Prevention of antibiotic-associated diarrhea in children by Clostridium butyricum MIYAIRI. Pediatr. Int. 2003, 45, 86-90. [CrossRef]

28. Yuzawa, T.; Kobayashi, A.; Inoue, H.; Enomoto, M. Twelve-Month Chronic Toxicity Study of Clostridium butyricum Miyairi Powder in Rats. Pharmacometrics 1987, 33, 683-694. 
29. Yuzawa, T.; Kobayashi, A.; Inoue, H.; Enomoto, M. A Five-Week Subacute Oral Toxicity and Recovery Test of Clostridium butyricum Miyairi Powder in Beagle Dogs. Pharmacometrics 1987, 34, 223-237.

30. Yuzawa, T.; Kobayashi, A.; Yamamoto, T.; Nakajima, M.; Inoue, H. Tests for the Acute Oral Toxicity in Rats and Mutagenicity of Clostridium butyricum Miyairi Powder. Pharmacometrics 1987, 34, 215-221.

31. Isa, K.; Oka, K.; Beauchamp, N.; Sato, M.; Wada, K.; Ohtani, K.; Nakanishi, S.; McCartney, E.; Tanaka, M.; Shimizu, T.; et al. Safety Assessment of the Clostridium butyricum MIYAIRI 588 ${ }^{\circledR}$ Probiotic Strain Including Evaluation of Antimicrobial Sensitivity and Presence of Clostridium Toxin Genes in Vitro and Teratogenicity in Vivo. Hum. Exp. Toxicol. 2016, 35, 818-832. [CrossRef]

32. Oka, K.; McCartney, E.; Ariyoshi, T.; Kudo, H.; Vilá, B.; de Jong, L.; Kozłowski, K.; Jankowski, J.; Morgan, S.; Kruger, C.; et al. In Vivo Safety Evaluation of the Clostridium butyricum MIYAIRI 588 Strain in Broilers, Piglets, and Turkeys. Toxicol. Res. Appl. 2019, 3, 2397847319826955. [CrossRef]

33. The European Commission. Commission Implementing Decision of 11 December 2014 authorising the placing on the market of Clostridium butyricum (CBM 588) as a novel food ingredient under Regulation (EC) No 258/97 of the European Parliament and of the Council (notified under document C (2014) 9345). OJEU 2014, 57, 153.

34. Hagihara, M.; Yamashita, R.; Matsumoto, A.; Mori, T.; Kuroki, Y.; Kudo, H.; Oka, K.; Takahashi, M.; Nonogaki, T.; Yamagishi, Y.; et al. The impact of Clostridium butyricum MIYAIRI 588 on the murine gut microbiome and colonic tissue. Anaerobe 2018, 54, 8-18. [CrossRef] [PubMed]

35. Hagihara, M.; Yamashita, R.; Matsumoto, A.; Mori, T.; Kuroki, Y.; Kudo, H.; Oka, K.; Takahashi, M.; Nonogaki, T.; Yamagishi, Y.; et al. The Impact of Clostridium Butyricum MIYAIRI 588 on Murine Gut Microbiome in Colonic Tissue. American Society for Microbiology (ASM) Microbe 2018, Atlanta, 2018, \#SUNDAY-85, Poster Presentation. Available online: https://asm.org/Events/ ASM-Microbe/Home (accessed on 19 January 2022).

36. Hagihara, M.; Yamashita, R.; Matsumoto, A.; Mori, T.; Kuroki, Y.; Kudo, H.; Oka, K.; Takahashi, M.; Nonogaki, T.; Yamagishi, Y.; et al. The Impact of Probiotics Clostridium Butyricum MIYAIRI 588 on Murine Gut Metabolic Alterations. American Society for Microbiology (ASM) Microbe 2018, Atlanta, 2018, \#SUNDAY-86, Poster Presentation. Available online: https: / /asm.org/Events / ASM-Microbe/Home (accessed on 19 January 2022).

37. Hagihara, M.; Yamashita, R.; Matsumoto, A.; Mori, T.; Inagaki, T.; Nonogaki, T.; Kuroki, Y.; Higashi, S.; Oka, K.; Takahashi, M.; et al. The impact of probiotic Clostridium butyricum MIYAIRI 588 on murine gut metabolic alterations. J. Infect. Chemother. 2019, 25, 571-577. [CrossRef] [PubMed]

38. Merga, Y.; Campbell, B.J.; Rhodes, J.M. Mucosal barrier b.bacteria and inflammatory bowel disease: Possibilities for therapy. Dig. Dis. 2014, 32, 475-483. [CrossRef]

39. Hagihara, M.; Kuroki, Y.; Yamashita, R.; Matsumoto, A.; Mori, T.; Nonogaki, T.; Oka, K.; Takahashi, M.; Yamagishi, Y.; Mikamo, H. Clostridium Butyricum MIYAIRI 588 Protect from the Colon Epithelial Damage Caused by Antimicrobials. American Society for Microbiology (ASM) Microbe 2019, San Francisco, 2019, \#FRIDAY-HMB-340, Poster Presentation. Available online: https:/ / asm.org/Events/ASM-Microbe/Home (accessed on 19 January 2022).

40. Hagihara, M.; Kuroki, Y.; Ariyoshi, T.; Higashi, S.; Fukuda, K.; Yamashita, R.; Matsumoto, A.; Mori, T.; Mimura, K.; Yamaguchi, N.; et al. Clostridium butyricum Modulates the Microbiome to Protect Intestinal Barrier Function in Mice with Antibiotic-Induced Dysbiosis. iScience 2020, 23, 100772. [CrossRef]

41. Ariyoshi, T.; Hagihara, M.; Eguchi, S.; Fukuda, A.; Iwasaki, K.; Oka, K.; Takahashi, M.; Yamagishi, Y.; Mikamo, H. Clostridium butyricum MIYAIRI 588-Induced Protectin D1 Has an Anti-inflammatory Effect on Antibiotic-Induced Intestinal Disorder. Front. Microbiol. 2020, 11, 587725. [CrossRef]

42. Levy, M.; Kolodziejczyk, A.A.; Thaiss, C.A.; Elinav, E. Dysbiosis and the immune system. Nat. Rev. Immunol. 2017, 17, 219-232. [CrossRef]

43. Vogt, S.L.; Finlay, B.B. Gut microbiota-mediated protect.tion against diarrheal infections. J. Travel Med. 2017, 24 (Suppl. S1), S39-S43. [CrossRef]

44. Allam-Ndoul, B.; Castonguay-Paradis, S.; Veilleux, A. Gut Microbiota and Intestinal Trans-Epithelial Permeability. Int. J. Mol. Sci. 2020, 21, 6402. [CrossRef]

45. Ahmadi, S.; Wang, S.; Nagpal, R.; Wang, B.; Jain, S.; Razazan, A.; Mishra, S.P.; Zhu, X.; Wang, Z.; Kavanagh, K.; et al. A humanorigin probiotic cocktail ameliorates aging-related leaky gut and inflammation via modulating the microbiota/taurine/tight junction axis. JCI Insight 2020, 5, e132055. [CrossRef]

46. Fukui, H. Leaky Gut and Gut-Liver Axis in Liver Cirrhosis: Clinical Studies Update. Gut Liver 2021, 15, 666-676. [CrossRef] [PubMed]

47. Yoo, J.Y.; Groer, M.; Dutra, S.V.O.; Sarkar, A.; McSkimming, D.I. Gut Microbiota and Immune System Interactions. Microorganisms 2020, 8, 1587, Erratum in Microorganisms 2020, 8, 2046. [CrossRef] [PubMed]

48. Fata, G.L.; Weber, P.; Mohajeri, M.H. Probiotics and the Gut Immune System: Indirect Regulation. Probiot. Antimicrob. Proteins 2018, 10, 11-21. [CrossRef] [PubMed]

49. Tickler, I.A.; Obradovich, A.E.; Goering, R.V.; Fang, F.C.; Tenover, F.C.; HAI Consortium. Changes in molecular epidemiology and antimicrobial resistance profiles of Clostridioides (Clostridium) difficile strains in the United States between 2011 and 2017. Anaerobe 2019, 60, 102050. [CrossRef]

50. Chandrasekaran, R.; Lacy, D.B. The role of toxins in Clostridium difficile infection. FEMS Microbiol. Rev. 2017, 41, 723-750. [CrossRef] 
51. Sun, X.; Savidge, T.; Feng, H. The enterotoxicity of Clostridium difficile toxins. Toxins 2010, 2, 1848-1880. [CrossRef]

52. Kelly, C.P.; LaMont, J.T. Clostridium difficile-more difficult than ever. N. Engl. J. Med. 2008, 359, 1932-1940, Erratum in N. Engl. J. Med. 2010, 363, 1585. [CrossRef]

53. Evans, C.T.; Safdar, N. Current Trends in the Epidemiology and Outcomes of Clostridium difficile Infection. Clin. Infect. Dis. 2015, 60 (Suppl. S2), S66-S71. [CrossRef]

54. Del Prete, R.; Ronga, L.; Addati, G.; Magrone, R.; Abbasciano, A.; Decimo, M.; Miragliotta, G. Clostridium difficile. A review on an emerging infection. Clin. Ter. 2019, 170, e41-e47. [CrossRef]

55. Li, C.; Duan, J.; Liu, S.; Meng, X.; Fu, C.; Zeng, C.; Wu, A. Assessing the risk and disease burden of Clostridium difficile infection among patients with hospital-acquired pneumonia at a University Hospital in Central China. Infection 2017, 45, 621-628. [CrossRef]

56. Czepiel, J.; Krutova, M.; Mizrahi, A.; Khanafer, N.; Enoch, D.A.; Patyi, M.; Deptuła, A.; Agodi, A.; Nuvials, X.; Pituch, H.; et al Mortality Following Clostridioides difficile Infection in Europe: A Retrospective Multicenter Case-Control Study. Antibiotics 2021, 10, 299. [CrossRef]

57. Fujii, H.; Maruyama, K.; Moriguti, M.; Sato, Y.; Takahashi, T.; Ito, K.; Yokoyama, H. Effect of Clostridium butyricum when Combined with Vancomycin in Treatment of Clostridium difficile-Associated Diarrhea. Iryo Yakugaku Jpn. J. Pharm. Health Care Sci. 2006, 32, 1009-1013. [CrossRef]

58. Oka, K.; Osaki, T.; Hanawa, T.; Kurata, S.; Sugiyama, E.; Takahashi, M.; Tanaka, M.; Taguchi, H.; Kamiya, S. Establishment of an Endogenous Clostridium difficile Rat Infection Model and Evaluation of the Effects of Clostridium butyricum MIYAIRI 588 Probiotic Strain. Front. Microbiol. 2018, 9, 1264. [CrossRef] [PubMed]

59. Kamiya, S.; Taguchi, H.; Yamaguchi, H.; Osaki, T.; Takahashi, M.; Nakamura, S. Bacterioprophylaxis using Clostridium butyricum for lethal caecitis by Clostridium difficile in gnotobiotic mice. Rev. Med. Microbiol. 1997, 8 (Suppl. S1), S60. [CrossRef]

60. Woo, T.D.H.; Oka, K.; Takahashi, M.; Hojo, F.; Osaki, T.; Hanawa, T.; Kurata, S.; Yonezawa, H.; Kamiya, S. Inhibition of the cytotoxic effect of Clostridium difficile in vitro by Clostridium butyricum MIYAIRI 588 strain. J. Med. Microbiol. 2011, 60, 1617-1625. [CrossRef]

61. Hagihara, M.; Ariyoshi, T.; Kuroki, Y.; Eguchi, S.; Higashi, S.; Mori, T.; Nonogaki, T.; Iwasaki, K.; Yamashita, M.; Asai, N.; et al. Clostridium butyricum enhances colonization resistance against Clostridioides difficile by metabolic and immune modulation. Sci. Rep. 2021, 11, 15007. [CrossRef]

62. Shen, A. A Gut Odyssey: The Impact of the Microbiota on Clostridium difficile Spore Formation and Germination. PLoS Pathog. 2015, 11, e1005157. [CrossRef]

63. Abbas, A.; Zackular, J.P. Microbe-microbe interactions during Clostridioides difficile infection. Curr. Opin. Microbiol. 2020, 53, 19-25. [CrossRef]

64. Carasi, P.; Trejo, F.M.; Pérez, P.F.; De Antoni, G.L.; Serradell, M.d.l.A. Surface proteins from Lactobacillus kefir antagonize in vitro cytotoxic effect of Clostridium difficile toxins. Anaerobe 2012, 18, 135-142. [CrossRef]

65. Castagliuolo, I.; Riegler, M.F.; Valenick, L.; LaMont, J.T.; Pothoulakis, C. Saccharomyces boulardii protease inhibits the effects of Clostridium difficile toxins A and B in human colonic mucosa. Infect. Immun. 1999, 67, 302-307. [CrossRef]

66. Nakanishi, S.; Tanaka, M. Sequence analysis of a bacteriocinogenic plasmid of Clostridium butyricum and expression of the bacteriocin gene in Escherichia coli. Anaerobe 2010, 16, 253-257. [CrossRef]

67. Hayashi, A.; Nagao-Kitamoto, H.; Kitamoto, S.; Kim, C.H.; Kamada, N. The Butyrate-Producing Bacterium Clostridium butyricum Suppresses Clostridioides difficile Infection via Neutrophil- and Antimicrobial Cytokine-Dependent but GPR43/109a-Independent Mechanisms. J. Immunol. 2021, 206, 1576-1585. [CrossRef]

68. Baj, J.; Forma, A.; Sitarz, M.; Portincasa, P.; Garruti, G.; Krasowska, D.; Maciejewski, R. Helicobacter pylori Virulence FactorsMechanisms of Bacterial Pathogenicity in the Gastric Microenvironment. Cells 2020, 10, 27. [CrossRef] [PubMed]

69. Handa, O.; Naito, Y.; Yoshikawa, T. Redox biology and gastric carcinogenesis: The role of Helicobacter pylori. Redox Rep. 2011, 16, 1-7, Erratum in Redox Rep. 2014, 19, 259. [CrossRef] [PubMed]

70. Handa, O.; Naito, Y.; Yoshikawa, T. Helicobacter pylori: A ROS-inducing bacterial species in the stomach. Inflamm. Res. 2010, 59, 997-1003. [CrossRef] [PubMed]

71. Sugano, K. Effect of Helicobacter pylori eradication on the incidence of gastric cancer: A systematic review and meta-analysis Gastric Cancer 2019, 22, 435-445. [CrossRef] [PubMed]

72. Sidebotham, R.L.; Worku, M.L.; Karim, Q.N.; Dhir, N.K.; Baron, J.H. How Helicobacter pylori urease may affect external pH and influence growth and motility in the mucus environment: Evidence from in-vitro studies. Eur. J. Gastroenterol. Hepatol. 2003, 15, 395-401. [CrossRef] [PubMed]

73. Yonezawa, H.; Osaki, T.; Fukutomi, T.; Hanawa, T.; Kurata, S.; Zaman, C.; Hojo, F.; Kamiya, S. Diversification of the AlpB Outer Membrane Protein of Helicobacter pylori Affects Biofilm Formation and Cellular Adhesion. J. Bacteriol. 2017, 199, e00729-16. [CrossRef]

74. Mukai, R.; Handa, O.; Suyama, Y.; Majima, A.; Naito, Y. Effectiveness of including probiotics to Helicobacter pylori eradication therapies. J. Clin. Biochem. Nutr. 2020, 67, 102-104. [CrossRef]

75. Imase, K.; Takahashi, M.; Tanaka, A.; Tokunaga, K.; Sugano, H.; Tanaka, M.; Ishida, H.; Kamiya, S.; Takahashi, S. Efficacy of Clostridium butyricum preparation concomitantly with Helicobacter pylori eradication therapy in relation to changes in the intestinal microbiota. Microbiol. Immunol. 2008, 52, 156-161. [CrossRef] 
76. Chen, L.; Xu, W.; Lee, A.; He, J.; Huang, B.; Zheng, W.; Su, T.; Lai, S.; Long, Y.; Chu, H.; et al. The impact of Helicobacter pylori infection, eradication therapy and probiotic supplementation on gut microenvironment homeostasis: An open-label, randomized clinical trial. eBioMedicine 2018, 35, 87-96. [CrossRef] [PubMed]

77. Satoh-Takayama, N.; Kato, T.; Motomura, Y.; Kageyama, T.; Taguchi-Atarashi, N.; Kinoshita-Daitoku, R.; Kuroda, E.; Di Santo, J.P.; Mimuro, H.; Moro, K.; et al. Bacteria-Induced Group 2 Innate Lymphoid Cells in the Stomach Provide Immune Protection through Induction of IgA. Immunity 2020, 52, 635-649.e4. [CrossRef]

78. Takahashi, M.; Taguchi, H.; Yamaguchi, H.; Osaki, T.; Kamiya, S. Studies of the effect of Clostridium butyricum on Helicobacter pylori in several test models including gnotobiotic mice. J. Med. Microbiol. 2000, 49, 635-642. [CrossRef]

79. Bernet, M.F.; Brassart, D.; Neeser, J.R.; Servin, A.L. Lactobacillus acidophilus LA 1 binds to cultured human intestinal cell lines and inhibits cell attachment and cell invasion by enterovirulent bacteria. Gut 1994, 35, 483-489. [CrossRef]

80. Kabir, A.M.; Aiba, Y.; Takagi, A.; Kamiya, S.; Miwa, T.; Koga, Y. Prevention of Helicobacter pylori infection by lactobacilli in a gnotobiotic murine model. Gut 1997, 41, 49-55. [CrossRef] [PubMed]

81. Erawijantari, P.P.; Mizutani, S.; Shiroma, H.; Shiba, S.; Nakajima, T.; Sakamoto, T.; Saito, Y.; Fukuda, S.; Yachida, S.; Yamada, T. Influence of gastrectomy for gastric cancer treatment on faecal microbiome and metabolome profiles. Gut 2020, 69, $1404-1415$. [CrossRef] [PubMed]

82. Eslami, M.; Bahar, A.; Keikha, M.; Karbalaei, M.; Kobyliak, N.M.; Yousefi, B. Probiotics function and modulation of the immune system in allergic diseases. Allergol. Immunopathol. 2020, 48, 771-788. [CrossRef] [PubMed]

83. Galdeano, C.M.; Cazorla, S.I.; Dumit, J.M.L.; Vélez, E.; Perdigón, G. Beneficial Effects of Probiotic Consumption on the Immune System. Ann. Nutr. Metab. 2019, 74, 115-124. [CrossRef]

84. Kaper, J.B.; Nataro, J.P.; Mobley, H.L. Pathogenic Escherichia coli. Nat. Rev. Microbiol. 2004, 2, 123-140. [CrossRef]

85. Balakrishnan, B.; Barizuddin, S.; Wuliji, T.; El-Dweik, M. A rapid and highly specific immunofluorescence method to detect Escherichia coli O157:H7 in infected meat samples. Int. J. Food Microbiol. 2016, 231, 54-62. [CrossRef]

86. Fujita, I.; Takahashi, M. Studies on the anti-diarrheal activity of Clostridium butyricum Miyairi II 588. Effects of Clostridium butyricum Miyairi II 588 on the enterotoxicity of the enterotoxins produced by enterotoxigenic Escherichia coli. Jpn. Pharmacol. Ther. 1987, 15, 55-62. (In Japanese)

87. Takahashi, M.; Taguchi, H.; Yamaguchi, H.; Osaki, T.; Komatsu, A.; Kamiya, S. The effect of probiotic treatment with Clostridium butyricum on enterohemorrhagic Escherichia coli O157:H7 infection in mice. FEMS Immunol. Med. Microbiol. 2004, 41, 219-226. [CrossRef] [PubMed]

88. Kunishima, H.; Ishibashi, N.; Wada, K.; Oka, K.; Takahashi, M.; Yamasaki, Y.; Aoyagi, T.; Takemura, H.; Kitagawa, M.; Kaku, $\mathrm{M}$. The effect of gut microbiota and probiotic organisms on the properties of extended spectrum beta-lactamase producing and carbapenem resistant Enterobacteriaceae including growth, beta-lactamase activity and gene transmissibility. J. Infect. Chemother. 2019, 25, 894-900. [CrossRef] [PubMed]

89. Humphreys, H. Staphylococcus aureus: The enduring pathogen in surgery. Surgeon 2012, 10, 357-360. [CrossRef]

90. Asao, T.; Kumeda, Y.; Kawai, T.; Shibata, T.; Oda, H.; Haruki, K.; Nakazawa, H.; Kozaki, S. An extensive outbreak of staphylococcal food poisoning due to low-fat milk in Japan: Estimation of enterotoxin A in the incriminated milk and powdered skim milk. Epidemiol. Infect. 2003, 130, 33-40. [CrossRef]

91. Bergdoll, M.S. Staphylococcus aureus. In Foodborne Bacterial Pathogens; Doyle, M.P., Ed.; CRC Press: New York, NY, USA, 1989; pp. 463-523.

92. Hou, Y.; Wang, L.; Yi, D.; Ding, B.; Chen, X.; Wang, Q.; Zhu, H.; Liu, Y.; Yin, Y.; Gong, J.; et al. Dietary supplementation with tributyrin alleviates intestinal injury in piglets challenged with intrarectal administration of acetic acid. Br. J. Nutr. 2014, 111, 1748-1758. [CrossRef]

93. Wu, J.Y.; Chen, D.F.; Wang, B.M.; Cao, H.L. Clostridium butyricum promotes ligands release from intestinal epithelial cells to activate epidermal growth factor receptor. Gastroenterology 2019, 156, S888-S889. [CrossRef]

94. Ma, M.; Zhao, Z.; Liang, Q.; Shen, H.; Zhao, Z.; Chen, Z.; He, R.; Feng, S.; Cao, D.; Gan, G.; et al. Overexpression of pEGF improved the gut protective function of Clostridium butyricum partly through STAT3 signal pathway. Appl. Microbiol. Biotechnol. 2021, 105, 5973-5991. [CrossRef]

95. Singleton, F.L.; Attwell, R.W.; Jangi, M.S.; Colwell, R.R. Influence of salinity and organic nutrient concentration on survival and growth of Vibrio cholerae in aquatic microcosms. Appl. Environ. Microbiol. 1982, 43, 1080-1085. [CrossRef]

96. Huq, A.; Small, E.B.; West, P.A.; Huq, M.I.; Rahman, R.; Colwell, R.R. Ecological relationships between Vibrio cholerae and planktonic crustacean copepods. Appl. Environ. Microbiol. 1983, 45, 275-283. [CrossRef]

97. Kuroiwa, T.; Kobari, K.; Iwanaga, M. Inhibition of enteropathogens by Clostridium butyricum MIYAIRI 588. Kansenshogaku Zasshi 1990, 64, 257-263. [CrossRef] [PubMed]

98. Andino, A.; Hanning, I. Salmonella enterica: Survival, colonization, and virulence differences among serovars. Sci. World J. 2015, 2015, 520179. [CrossRef] [PubMed]

99. Kunstmann, L.; Meedom, L.; Hautekiet, V.; Veken, W.V.; Andersen, A.A. Reduction of Salmonella Serotiters by Clostridum Butyricum in a Commercial Pig Trial. In Proceedings of the ESPHM 2019, Utrecht, The Netherlands, $22-24$ May 2019; VPH-PP-01, Poster Presentation. 
100. Zhao, X.; Yang, J.; Ju, Z.; Wu, J.; Wang, L.; Lin, H.; Sun, S. Clostridium butyricum Ameliorates Salmonella Enteritis Induced Inflammation by Enhancing and Improving Immunity of the Intestinal Epithelial Barrier at the Intestinal Mucosal Level. Front. Microbiol. 2020, 11, 299. [CrossRef] [PubMed]

101. Verma, A.K.; Verma, R.; Ahuja, V.; Paul, J. Real-Time Analysis of Gut Flora in Entamoeba Histolytica Infected Patients of Northern India. BMC Microbiol. 2012, 12, 183. [CrossRef]

102. The, H.C.; de Sessions, P.F.; Jie, S.; Thanh, D.P.; Thompson, C.N.; Minh, C.N.N.; Chu, C.W.; Tran, T.-A.; Thomson, N.R.; Thwaites, G.E.; et al. Assessing Gut Microbiota Perturbations during the Early Phase of Infectious Diarrhea in Vietnamese Children. Gut Microbes 2018, 9, 38-54. [CrossRef] [PubMed]

103. Tachikawa, T.; Seo, G.; Nakazawa, M.; Sueyoshi, M.; Ohishi, T.; Joh, K. Estimation of probiotics by infection model of infant rabbit with enterohemorrhagic Escherichia coli O157:H7. Kansenshogaku Zasshi 1998, 72, 1300-1305. [CrossRef] [PubMed]

104. Liu, H.; Wang, J.; He, T.; Becker, S.; Zhang, G.; Li, D.; Ma, X. Butyrate: A Double-Edged Sword for Health? Adv. Nutr. 2018, 9 , 21-29. [CrossRef]

105. Jenab, A.; Roghanian, R.; Emtiazi, G. Bacterial Natural Compounds with Anti-Inflammatory and Immunomodulatory Properties (Mini Review). Drug Des. Devel Ther. 2020, 14, 3787-3801. [CrossRef]

106. Li, M.; van Esch, B.C.A.M.; Wagenaar, G.T.M.; Garssen, J.; Folkerts, G.; Henricks, P.A.J. Pro- and anti-inflammatory effects of short chain fatty acids on immune and endothelial cells. Eur. J. Pharmacol. 2018, 831, 52-59. [CrossRef] [PubMed]

107. Yajima, T. Sensory mechanisms for SCFA in the colon. In Physiological and Clinical Aspects of Short-Chain Fatty Acids; Cummings, J.H., Rombeau, J.L., Sakata, T., Eds.; Cambridge University Press: Cambridge, UK, 1995; pp. 209-221.

108. Yajima, T. Effect of Sodium Propionate on the Contractile Response of the Rat Ileum in Situ. Jpn. J. Pharmacol. 1984, 35, 265-271. [CrossRef]

109. Grider, J.R.; Piland, B.E. The peristaltic reflex induced by short-chain fatty acids is mediated by sequential release of 5-HT and neuronal CGRP but not BDNF. Am. J. Physiol. Gastrointest. Liver Physiol. 2007, 292, G429-G437. [CrossRef] [PubMed]

110. Cherbut, C. Effects of SCFA from the large intestine. In Physiological and Clinical Aspects of Short-Chain Fatty Acids; Cummings, J.H., Rombeau, J.L., Sakata, T., Eds.; Cambridge University Press: Cambridge, UK, 1995; pp. 191-207.

111. Shimotoyodome, A.; Meguro, S.; Hase, T.; Tokumitsu, I.; Sakata, T. Short chain fatty acids but not lactate or succinate stimulate mucus release in the rat colon. Comp. Biochem. Physiol. Part A 2000, 125, 525-531. [CrossRef]

112. Maslowski, K.M.; Vieira, A.T.; Ng, A.; Kranich, J.; Sierro, F.; Yu, D.; Schilter, H.C.; Rolph, M.S.; Mackay, F.; Artis, D.; et al. Regulation of inflammatory responses by gut microbiota and chemoattractant receptor GPR43. Nature 2009, 461, 1282-1286. [CrossRef] [PubMed]

113. Arpaia, N.; Campbell, C.; Fan, X.; Dikiy, S.; van der Veeken, J.; de Roos, P.; Liu, H.; Cross, J.R.; Pfeffer, K.; Coffer, P.J.; et al. Metabolites produced by commensal bacteria promote peripheral regulatory T-cell generation. Nature 2013, 504, 451-455. [CrossRef]

114. Furusawa, Y.; Obata, Y.; Fukuda, S.; Endo, T.A.; Nakato, G.; Takahashi, D.; Nakanishi, Y.; Uetake, C.; Kato, K.; Kato, T.; et al. Commensal microbe-derived butyrate induces the differentiation of colonic regulatory T cells. Nature 2013, 504, 446-450, Erratum in Nature 2014, 506, 254. [CrossRef] [PubMed]

115. Ariyoshi, T.; Hagihara, M.; Tomono, S.; Eguchi, S.; Minemura, A.; Miura, D.; Oka, K.; Takahashi, M.; Yamagishi, Y.; Mikamo, H. Clostridium butyricum MIYAIRI 588 Modifies Bacterial Composition under Antibiotic-Induced Dysbiosis for the Activation of Interactions via Lipid Metabolism between the Gut Microbiome and the Host. Biomedicines 2021, 9, 1065. [CrossRef]

116. Fujii, T.; Jounai, K.; Horie, A.; Takahashi, H.; Suzuki, H.; Ohshio, K.; Fujiwara, D.; Yamamoto, N. Effects of Heat-Killed Lactococcus Lactis Subsp. Lactis JCM 5805 on Mucosal and Systemic Immune Parameters, and Antiviral Reactions to Influenza Virus in Healthy Adults; a Randomized Controlled Double-Blind Study. J. Funct. Foods 2017, 35, 513-521. [CrossRef]

117. Tsuji, R.; Yamamoto, N.; Yamada, S.; Fujii, T.; Yamamoto, N.; Kanauchi, O. Induction of Anti-Viral Genes Mediated by Humoral Factors upon Stimulation with Lactococcus Lactis Strain Plasma Results in Repression of Dengue Virus Replication in Vitro. Antivir. Res. 2018, 160, 101-108. [CrossRef]

118. Iwabuchi, N.; Xiao, J.-Z.; Yaeshima, T.; Iwatsuki, K. Oral Administration of Bifidobacterium Longum Ameliorates Influenza Virus Infection in Mice. Biol. Pharm. Bull. 2011, 34, 1352-1355. [CrossRef]

119. Morita, M.; Kuba, K.; Ichikawa, A.; Nakayama, M.; Katahira, J.; Iwamoto, R.; Watanebe, T.; Sakabe, S.; Daidoji, T.; Nakamura, S.; et al. The Lipid Mediator Protectin D1 Inhibits Influenza Virus Replication and Improves Severe Influenza. Cell 2013, 153, 112-125. [CrossRef] 